\title{
Class Reproduction and Re-Formation during Young People's Education to Employment Transitions in South and East Mediterranean Countries ${ }^{1}$
}

\author{
By Ken Roberts* \\ Siyka Kovacheva ${ }^{\dagger}$ \\ Stanimir Kabaivanov ${ }^{*}$
}

This paper uses evidence from surveys in 2015-16 of nationally representative samples comprising approximately 2000 15-29 year olds in each of five South and East Mediterranean countries. We focus on those aged 25-29 who had nearly all completed their education. We analyse the job characteristics of those in employment and identify four main employment classes. Just two of these, a business class and a salariat, are found to have survived since the careers of the samples' parents were constructed. These advantaged classes alone are found to possess demographic coherence: high probability of individuals remaining in their classes, distinctive life chances of children born into these classes, and characteristic adult biographies of those who reach these class destinations. While sometimes acting as a channel for social mobility, education is also found to screen and render opaque the extent and processes whereby class advantages are transmitted inter-generationally.

Keywords: education, labour markets, Middle East, North Africa, social class, youth.

\section{Introduction}

Aims

This paper uses evidence from quantitative surveys of nationally representative samples of approximately 2000 15-29 year olds in each of five South and East Mediterranean (SEM), Arab majority countries - Algeria, Egypt, Lebanon, Morocco and Tunisia. The aims are:

i. To identify the main employment classes among the male and female respondents who had entered their countries' labour markets.

ii. To assess how the countries' class structures had changed intergenerationally from their parents to our respondents' labour market careers commencing.

\footnotetext{
*Emeritus Professor, University of Liverpool, UK.

${ }^{\dagger}$ Professor, University of Plovdiv, Bulgaria.

*Professor, University of Plovdiv, Bulgaria.

${ }^{1}$ This paper has been prepared within the research project FP7-SSH-2013-2 SAHWA: empowering the young generation; towards a new social contract in South and East Mediterranean countries.
} 
iii. To measure the extent of inter-generational, parent to offspring, inheritance of class positions as one contributor to the demographic coherence of the employment classes that are identified.

iv. To show that rather than an alternative, the application of a youth transitions paradigm is an effective way to identify inter-generational changes.

v. To illustrate how employment classes can be reproduced inter-generationally amid major macro socio-economic transformations.

We treat demographic coherence as a necessary condition for the development of employment classes into social classes with additional distinctive socio-cultural characteristics, and possibly political proclivities.

\section{Youth Research}

Youth researchers occupy a privileged position for studying inter-generational continuity and change, immobility and mobility, in individuals' social class locations, and also macro-changes in class structures themselves. This is because the subject matter (youth) requires the entire life stage to be scanned. At one edge we see young people loosening links with their childhood families and completing early stages of schooling. At the other edge we see young adults starting employment careers and forming new family households. Of course, we must always recognise that some individuals may never settle, and that nomadic adulthoods, a kind of perpetual youth, may become a new normal. Crucially, youth researchers focus on intervening stages - the sequences of experiences in post-compulsory and tertiary education, training and employment, relationships with peers and housing careers - that connect childhood origins to adult destinations. Thus youth researchers can perceive how continuities and changes in individuals' class locations are accomplished, and it is only at the upper end of the youth life stage that it becomes possible to learn how much of what happened subsequently was predictable from the individuals' childhoods, and how this predictability was possible.

A complication and a challenge which youth researchers are uniquely able to meet is that in changing societies it is impossible for upcoming cohorts to replicate their parents' lives. Hence recent calls for researchers to pay more attention to how today's young people are experiencing and helping to create, always within constraining contexts, a new youth and new adulthood (see Woodman and Wyn 2015). In Western countries in the mid-to-late $20^{\text {th }}$ century enrolments in higher education rose, and there were shifts in employment from manual into non-manual occupations. This led to changes in the social significance, including the labour market value, of a university degree. In the $21^{\text {st }}$ century many older working class, manual jobs in which individuals could expect indefinite employment for 48, 44, 40 or 35 hours during 50, 48 or 46 weeks per year have been replaced by so-called gig economy jobs in which people are hired and dismissed, employed and paid, according to fluctuating 
workflows. Young people are invariably in the front line, among the first to be affected, and among whom new class formations can be detected. Major changes may disrupt the inter-generational reproduction of class positions, and may disorganise classes themselves. However, our evidence from South and East Mediterranean (SEM) countries illustrates how class reproduction can continue and classes can retain coherence amid major macro-transformations. We will present evidence on rates and patterns of inter-generational mobility and immobility within our samples, but this is not the principal issue that we address. Our interest in social mobility here is primarily in the roles of immobility and mobility in strengthening or weakening the demographic coherence of different employment-based classes.

\section{Class}

This is among the most frequently used and also one of the most contested concepts in sociology. Any class researcher has to make a series of conceptual choices. None can be proved right or wrong: only that the one selected has worked for investigators in the past and is fit for the current researchers' purposes.

Our first choice is to insist that classes are most fundamentally economic formations, composed of individuals and households that occupy common positions in a society's systems of economic production, distribution and therefore consumption opportunities. This has been the conventional choice in sociology. It follows both Marx's and Weber's work on class. Economic positions are usually indicated by occupations which are grouped into classes on the basis of their typical status, employment relations, work situations, incomes or workers' close associates (marital partners or friends).Sometimes additional indicators education and housing - have been added to create composite class scales. The most recent innovation, pioneered in The Great British Class Survey (Savage et al. 2013) has been to add social associates and cultural tastes to income and wealth. These investigators claim that their class concept is inspired by the work of Pierre Bourdieu, but Bourdieu's own classes were groups of occupations which were then shown to be additionally distinguishable by their cultural tastes (Bourdieu 1979, Bourdieu and Passeron 1970). Our view is that while classes may be further united by social bonds and shared tastes; these matters should be settled by evidence, not by definition. We do not consider it realistic for sociology to allow individuals to change the classes to which they are allocated simply by changing their tastes. Our working assumption is that while economic classes may be strengthened by developing social and cultural dimensions which further set them apart from other classes, and which then may assist a class to become a political actor, whether these developments occur can vary by time and place, and between classes within any society. Another working assumption is that a pre-condition for any of the above to happen is that a class should achieve demographic coherence, meaning that clear majorities of members should retain their class positions throughout their employment careers, that their children should have characteristic (but not 
necessarily common) life chances which make the classes distinctive, and that adult members should have reached their class positions through characteristic (but not necessarily common) sequences of prior experiences. A high level (the more the better) of inter-generational continuity in class locations will always contribute to demographic coherence.

A second conceptual decision required by quantitative researchers is whether to treat class as an interval or categorical variable. Both procedures have committed supporters. Interval variables place occupations along a scale with no clear breaks or divisions. The class structure can then be likened to a ladder and the rungs that individuals occupy can be said to depend on their qualifications, skills, experience, effort and raw talent. Occupations are usually ranked by status or income (an example is Ganzeboom et al. 1992), but the Cambridge Scale ranks occupations according to which other occupations members of a first occupation tend to associate with as friends and marital partners (Prandy 1990, 1998). The justification for conceptualising class gradationally is that all economic inequalities are distributed in this way: income and also job characteristics such as security, autonomy and authority. The case for treating class categorically is that all these inequalities cluster, thereby separating occupations into metaphorical clumps, and that the clustering occurs because classes are formed relationally - employing and being employed, managing and being managed, conceiving and performing work tasks (see Rose 1998, Rose and Harrison 2007 for defences and examples of categorical class schemes). There need be no metaphorical ditches or walls separating different classes. At the margins adjacent classes may merge into one another. Only categorical classes open the possibility that discrete economic aggregates will develop the demographic coherence to which social and cultural bonds can be added, which is what we are seeking in SEM countries. Therefore a categorical class concept best serves our purposes.

A third conceptual choice that cannot be avoided concerns the unit to classify, individuals or family households. The conventional practice in Western sociology used to be to classify households according to the male head of household's occupation, later modified to the occupation of the main earner. Thirty years ago John Goldthorpe was an unrepentant defender of this conventional practice (see Erikson and Goldthorpe 1988, Goldthorpe 1983). Since then what was once conventional has become extinct due to women's rising rates of labour force participation, coupled with young women remaining single for longer, then facing rising risks of divorce and separation, leading to recognition that their life chances depend more on their own qualifications and occupations than who they marry. Joint classification, taking account of husbands' and wives' occupations was briefly considered then rejected for attributing common class positions to households that might share nothing in common, and its incompatibility with a categorical concept of class. Thus individual classification is the new conventional practice (early advocates include Charles 1990, Leiulfsrud and Woodward 1987, Stanworth 1984). We opt to privilege males' class positions for the pragmatic reason that in SEM countries most young women never enter the labour market. However, women remain in sight throughout our analysis and are foregrounded 
when we see how those who enter employment enhance the distinctiveness of one of the two main classes that we identify.

The final decision to make when Western class researchers engage with other parts of the world is whether to classify the populations using class schemes or scales developed for use in their own countries, as in Evans and Mills' research in the new market economies of post-communist countries in the 1990s (Evans and Mills 1999). The alternative, which we adopt here, following Roberts and Pollock's $(2009,2011)$ research in the South Caucasus, is to purpose-build aclass scheme using evidence from the countries that we have investigated.

\section{Evidence}

This is from interview surveys in 2015-16 using a fully structured questionnaire that was available in Arabic, French and English. All interviews were conducted by a same-sex interviewer. The respondents were 15-29 year olds who were resident sin nationally representative samples of households in five SEM countries (Algeria, Egypt, Lebanon, Morocco and Tunisia).

Respondents were asked about their families of origin (mothers' and fathers' education and occupations), their own education and highest qualifications at that time, whether they were single, in a relationship, married, divorced, separated or widowed, their types of housing and tenure, plus household facilities and furnishings, and whether they were living independently from their parents. When a husband or wife was co-resident, his or her age, education and employment status were recorded, as was the presence of any co-resident children. There were also questions about political and religious attitudes and behaviour, uses of old and new media and other uses of free time which we do not use in this paper. Here we focus on respondents' past experiences and current locations in or out of their countries' labour markets from which we identify their class positions at the time of the survey, the destinations reached by individuals from different family and educational backgrounds, the sequences of movements whereby they had reached their destinations, and variations by gender, countries and whether respondents lived in rural or urban settlements.

Up to now there has been a serious deficit of comprehensive data on class divisions in the SEM region. This has been due to the huge inter- and intra-country variations in socio-economic contexts, and the absence of the development, and region-wide use, of a comprehensive class scheme based on evidence from the region (see Farsoun 2006, Storm 2014, United Nations Economic and Social Commission for Western Asia 2014). However, all authors agree that all the countries possess upper classes composed of major landowners and stakeholders in major businesses, who everywhere enjoy mutually beneficial relationships with the political elites (see Allison 2015, Shenker 2016). As happens in all surveys of nationally representative samples, this upper class is too small to be identified in our data. However, it is indisputably the most powerful class in all the countries, and always governs, directly or indirectly, the formation of other employment classes. 


\section{Results}

\section{Constructing Classes}

No researcher identifies social classes that exists ready-made, awaiting discovery. There is always a substantial input by researchers, quantitative and qualitative, who decide where to look, what to ask, and how to analyse and interpret their findings.

Table 1. Positions Vis-A-Vis the Labour Market in Age Groups (All Countries), (in \%)

\begin{tabular}{|l|c|c|c|c|c|c|}
\hline & \multicolumn{3}{|c|}{ Males } & \multicolumn{3}{c|}{ Females } \\
\cline { 2 - 7 } & $\mathbf{1 5 - 1 9}$ & $\mathbf{2 0 - 2 4}$ & $\mathbf{2 5 - 2 9}$ & $\mathbf{1 5 - 1 9}$ & $\mathbf{2 0 - 2 4}$ & $\mathbf{2 5 - 2 9}$ \\
\hline Education & 69 & 35 & 7 & 74 & 33 & 5 \\
\hline Employer & $<1$ & 2 & 5 & $<1$ & $<1$ & 1 \\
\hline Self-Employed & 2 & 7 & 14 & 1 & 2 & 4 \\
\hline Employee & 13 & 27 & 47 & 3 & 10 & 22 \\
\hline Apprentice & 2 & 1 & 2 & $<1$ & 1 & 1 \\
\hline Family Worker & 3 & 3 & 3 & 1 & 1 & 2 \\
\hline Unemployed & 4 & 11 & 14 & 2 & 9 & 10 \\
\hline Inactive & 8 & 15 & 9 & 18 & 43 & 55 \\
\hline N & 1826 & 1884 & 1566 & 1526 & 1541 & 1517 \\
\hline
\end{tabular}

Our interviews required respondents to assign themselves to one of the labour market groups in Table 1. Those still in education, employers, the self-employed, employees, apprentices and family workers placed themselves in these groups. Those who called themselves unemployed and inactive were treated differently. The self-described unemployed were left in this group only if they met the International Labour Office criteria which are routinely applied in countries' labour force surveys. They should not have done any work but should have actively searched for jobs during the last seven days, and be prepared to start more or less immediately if offered suitable jobs. Any who did not meet these tests were re-allocated to the inactive group. Correspondingly, those who self-described as inactive or who had been reallocated to the inactive group were placed in the unemployed group if they were seeking employment. Two immediately noteworthy points are, first, that most 25-29 year old women (55\%) were inactive, and among those who had left education, in both younger age groups the inactive outnumbered those who were active in the labour market. Farsoun (2006) claims that economic inactivity has been rising throughout the region in recent decades due to the commercialisation of agriculture - the replacement of small family farms by larger agri-businesses - and the reluctance of females to work outside their families. Second, nearly a third of 25-29 year old males with any employment were working for themselves as family workers, employers or selfemployed. This is a pre-industrial employment profile which by the $21^{\text {st }}$ century had spread into the region's cities. 
Table 2. Monthly Incomes of 25-29 Year Olds in Euro ppp

\begin{tabular}{|l|c|c|c|c|c|c|}
\hline & \multicolumn{4}{|l|}{ Lebanon } & \multicolumn{3}{|c|}{ Algeria, Egypt, Morocco and Tunisia } \\
\hline & Employers & $\begin{array}{c}\text { Self- } \\
\text { Employed }\end{array}$ & Employees & Employers & $\begin{array}{c}\text { Self- } \\
\text { Employed }\end{array}$ & Employees \\
\hline $\begin{array}{l}\text { Top } \\
\text { Quartile }\end{array}$ & 3362 & 2073 & 1484 & 1235 & 821 & 656 \\
\hline Median & 1681 & 1233 & 1137 & 520 & 547 & 508 \\
\hline $\begin{array}{l}\text { Bottom } \\
\text { Quartile }\end{array}$ & 1121 & 784 & 672 & 328 & 358 & 273 \\
\hline
\end{tabular}

We gathered additional evidence about respondents' jobs, if any. Those who were earning were asked about their monthly incomes. Answers were recorded in the local currencies then converted into Euro at purchasing power parity (ppp). In Lebanon employers had by far the highest incomes, then the self-employed, then employees, but with wide inequalities within each group (see Table 2). Those with earned incomes were divided into quartiles. Earnings were similar in Algeria, Egypt, Morocco and Tunisia, and their data are aggregated in calculating medians, upper and lower quartiles. In these countries it was only employers who were top quartile earners whose incomes clearly exceeded those of their self-employed and employee counterparts. In Lebanon typical earnings were over twice as high as in the other countries, so Lebanon incomes are split into quartiles using just Lebanon data. In all cases forth with the medians, upper and lower quartiles are for employees' incomes, which are also applied to the incomes of employers and the self-employed.

We asked whether employees' jobs were in the private or public sector: $86 \%$ were in the former. We also asked whether employees had written contracts of employment and, if so, whether these were of indefinite duration, temporary, or for state employment measures: $77 \%$ of public sector employees against just $30 \%$ in the private sector had written contracts of some description. Most private sector employment and self-employment was informal. We asked whether employees were insured in their countries' state social security schemes: $71 \%$ in the public sector against $26 \%$ in the private sector had this insurance. We also asked how many hours employees worked per day and how many days per week, but these questions proved less discriminating than we had anticipated, a working day normally lasted eight hours in the public and private sectors, but whereas public sector employees worked five days per week, in the private sector it was usually six days. This was one advantage of public sector jobs. The other advantages were the enhanced security (with written contracts), and generally higher pay. Everyone was asked about previous jobs (if any). These items of information are used to construct the employment classes in Table 3. 
Table 3. Employment Classes by Age Groups (in \%)

\begin{tabular}{|l|c|c|c|c|c|c|}
\hline \multicolumn{3}{|c|}{ Males } & \multicolumn{3}{c|}{ Females } \\
\hline & $\mathbf{1 5 - 1 9}$ & $\mathbf{2 0 - 2 4}$ & $\mathbf{2 5 - 2 9}$ & $\mathbf{1 5 - 1 9}$ & $\mathbf{2 0 - 2 4}$ & $\mathbf{2 5 - 2 9}$ \\
\hline Still In Education & 70 & 37 & 7 & 75 & 34 & 5 \\
\hline 1a. Business Class & $<1$ & 2 & 8 & $<1$ & $<1$ & 2 \\
\hline $\begin{array}{l}\text { 1b. Sub-Business } \\
\text { Class }\end{array}$ & 1 & 4 & 8 & $<1$ & 1 & 1 \\
\hline 2a. Salariat & $<1$ & 2 & 9 & 0 & 1 & 7 \\
\hline 2b.Sub-Salariat & $<1$ & 1 & 3 & 0 & 1 & 2 \\
\hline 3. Informals & 6 & 15 & 26 & 1 & 5 & 9 \\
\hline 4. Precariat & 12 & 18 & 23 & 4 & 10 & 14 \\
\hline 5. Detached & 11 & 23 & 16 & 20 & 50 & 61 \\
\hline N & 1778 & 1789 & 1469 & 1516 & 1515 & 1477 \\
\hline
\end{tabular}

- Class 1a, the business class, were employers or self-employed with incomes within the top quartile for employees. Class $1 \mathrm{~b}$ had lower incomes, but within the two middle quartiles.

- Class 2a, the salariat, had written employment contracts of indefinite duration and incomes within the top quartile. Class $2 b$ were different in their incomes being lower but within the two middle quartiles.

The reason for separating the 'subs', the fringe members, from the main classes $1 \mathrm{a}$ and $2 \mathrm{a}$, is that demographic coherence, then matching social practices and cultural proclivities, are most likely to develop and be detectable among any class's most characteristic, core members.

- Class 3 is composed of informal employees (who had no written contracts of employment) with incomes above the bottom quartile.

- Class 4, the precariat, contains everyone in any kind of employment whose income was in the bottom quartile, plus the unemployed and inactive who had past records of employment. Approximately a half of the selfemployed were members of this precariat.

- This leaves Class 5, the detached, with no histories of any type of employment and who were not seeking employment.

We are classifying individuals by characteristics of their jobs rather than occupational titles. In this respect we are following the preference of Erik Olin Wright $(1979,1985,1994,1996,2000)$. We collected the necessary evidence about job characteristics, and we realised that occupational titles were less likely to be accurate indicators of class boundaries than they have been in Western and communist countries. Whether a job was formal or informal, and the pay, overrode the significance of whether someone was working as a journalist, driver, market trader or whatever. However, in other respects we depart from Wright's methods of constructing classes. Our defence again is respect for the realities of the labour markets that we were investigating.

There are interval as well as categorical features in our class scheme. Income 
is the interval feature and its inclusion is essential in order to incorporate consumption opportunities. The breaks and categories are introduced by employment relations: being an employee or a boss, having or not having a written contract of employment, and being attached, however loosely, or completely outside the labour market.

The wide income inequalities between our employment classes, differences in their work situations, and in their terms and conditions of employment, were not reflected in the samples' self-assessed class positions when they were asked to place themselves along a 0-10 scale. All the classes' mean ratings clustered around the middle (see Table 4). Two quirks are that females consistently ranked themselves higher than males in the same classes and male and female subs ranked themselves above the salariat proper as did female subs of the business class proper. However, the self-rankings align with our class scheme in that the business class and salariat proper, plus their subs, gave themselves higher ratings than respondents in any of the other classes.

Table 4. Self-Assessed Class Positions: Mean Ratings

\begin{tabular}{|l|c|c|}
\hline & Males & Females \\
\hline 1a. Business Class & 4.9 & 5.0 \\
\hline 1b. Sub-Business Class & 4.5 & 5.7 \\
\hline 2a. Salariat & 4.9 & 5.0 \\
\hline 2b.Sub-Salariat & 5.1 & 5.3 \\
\hline 3. Informals & 4.3 & 4.6 \\
\hline 4. Precariat & 4.1 & 4.6 \\
\hline 5. Detached & 4.0 & 4.6 \\
\hline
\end{tabular}

\section{Descriptive Comparisons}

Table 5a. Employment Classes by Countries, 25-29 Year Olds, Males (in \%)

\begin{tabular}{|l|c|c|c|c|c|}
\hline & Algeria & Egypt & Lebanon & Morocco & Tunisia \\
\hline Still in Education & 10 & 2 & 7 & 14 & 5 \\
\hline 1a. Business Class & 8 & 1 & 26 & 1 & 2 \\
\hline 1b. Sub-Business v Class & 7 & 7 & 6 & 16 & 2 \\
\hline 2a. Salariat & 5 & 1 & 24 & 7 & 4 \\
\hline 2b.Sub-Salariat & 3 & 7 & $<1$ & 3 & 3 \\
\hline 3. Informals & 27 & 38 & 27 & 17 & 18 \\
\hline 4. Precariat & 16 & 38 & 6 & 18 & 40 \\
\hline 5. Detached & 26 & 6 & 4 & 24 & 24 \\
\hline N & 308 & 283 & 332 & 223 & 324 \\
\hline
\end{tabular}

Forthwith we restrict our analysis to 25-29 year olds who had mostly completed their transitions from full-time education to whatever came next. Table 5 compares the class distributions of males and females in the five countries. It shows that Lebanon had a relatively large business class (26\% of males) and a large female salariat (19\% of 25-29 year old women). Egypt had a relative high proportion of males in informal jobs (38\%) and more detached women $(80 \%)$ than 
any other country. Egypt and Tunisia had relatively high proportions of males in their precariats (38\% and 40\%), but just Tunisia among its females (27\%).

Table 5b. Employment Classes by Countries, 25-29 Year Olds, Females (in \%)

\begin{tabular}{|l|c|c|c|c|c|}
\hline & Algeria & Egypt & Lebanon & Morocco & Tunisia \\
\hline Still in Education & 5 & 2 & 3 & 13 & 7 \\
\hline 1a. Business Class & 1 & - & 5 & - & 1 \\
\hline 1b. Sub-Business Class & 2 & - & 1 & 3 & $<1$ \\
\hline 2a. Salariat & 4 & $<1$ & 19 & - & 3 \\
\hline 2b.Sub-Salariat & 3 & 3 & 1 & 2 & 1 \\
\hline 3. Informals & 9 & 3 & 17 & 5 & 8 \\
\hline 4. Precariat & 10 & 12 & 6 & 13 & 27 \\
\hline 5. Detached & 64 & 80 & 49 & 64 & 54 \\
\hline N & 280 & 313 & 385 & 129 & 370 \\
\hline
\end{tabular}

A point that we can note here is that the class structures of the SEM countries are bottom-heavy, pyramid shaped. They are unlike the present-day class structures of Western countries which during the $20^{\text {th }}$ century changed from pyramid to diamond shaped, then subsequently to resemble pillars, and then in some countries bulges at the bottom appeared due to the spread of 'gig economy' jobs.

Male-female differences have already been summarised in Table 3. Females were by far the more likely to be detached, and males were more likely to be in all the employed classes. The gender gaps among 25-29 year olds were narrowest in the business class (7\% and 5\%), the salariat (9\% and 7\%) and the sub-salariat (3\% and $2 \%$ ).

Table 6. Employment classes by place of residence, 25-29 year olds (in \%)

\begin{tabular}{|l|c|c|c|c|}
\hline \multicolumn{2}{|c|}{ Males } & \multicolumn{2}{c|}{ Females } \\
\hline Still in Education & Urban & Rural & Urban & Rural \\
\hline 1a. Business Class & 9 & 5 & 6 & 4 \\
\hline $\begin{array}{l}\text { 1b. Sub-Business } \\
\text { Class }\end{array}$ & 8 & 7 & 2 & 1 \\
\hline 2a. Salariat & 12 & 3 & 1 & 1 \\
\hline 2b.Sub-Salariat & 3 & 3 & 10 & 2 \\
\hline 3. Informals & 24 & 29 & 12 & 2 \\
\hline 4. Precariat & 19 & 31 & 14 & 14 \\
\hline 5. Detached & 17 & 14 & 53 & 73 \\
\hline N & 914 & 555 & 907 & 570 \\
\hline
\end{tabular}

The main urban-rural differences are that urban males were more likely to be in the business class (9\% and $5 \%$ ) and salariat (12\% and 3\%), while more of their rural counterparts were employed informally (24\% and 29\%) and in the precariat $(19 \%$ and $31 \%)$. Among females those in rural areas were the more likely to be detached $(53 \%$ and $73 \%$ ) while more of their urban counterparts were in all the employed classes except the precariat. The female urban-rural gap was widest in 
the salariat (10\% and 2\%) and informal employment (12\% and 4\%).

\section{Continuity in Employment Class Positions}

The first test of demographic coherence is whether individuals remain within a class throughout their working lives. In the case of our respondents, only time will tell conclusively. However, members of classes 1a and 2a, those running businesses successfully and succeeding in salaried employment had no reason to change. Those in classes $1 \mathrm{~b}$ and $2 \mathrm{~b}$ could move up or slip down into class 3 . Members of class 3, individuals in informal employment, were unlikely to move up. At age 25-29 they had shown no aptitude for business and faced competition from younger cohorts for any vacant salariat jobs. Their best hope was to move up the hierarchy of informal jobs which are judged primarily by pay, then by how the employees are treated - considerately or otherwise (see Montieth and Giesbert 2016). Class 3 individuals could alternatively slip down into the precariat, some of whose members could rise into better-paid jobs. Those with no records of employment at age 25-29 were most likely to remain 'detached'. In our view, classes 1a and 2a have the best prospects of continuing in these positions, and we shall see below that they were the best demographically formed classes in terms of sharing life chances and biographies.

\section{Class Origins and Life Chances}

Before a group of jobs can be described as an employment class it must exhibit demographic coherence. This means, first, continuity of occupancy of class positions, which we are unable to test, then second it means that different class origins should confer class-characteristic, distinctive life chances.

Western sociology, and indeed Western societies, treat education as the key to life chances. Advantaged parents try to ensure that their children attend schools where they are most likely to succeed, and then progress into top universities. Widening participation in higher education is now the preferred way of equalising life chances. The SEM countries are no different. Over the last 50 years they have all built mass education systems. Illiteracy has been all but eradicated among young people. First primary schooling, then completion of full secondary education has become normal in all social strata. More recently it has been higher education. Just $10 \%$ of respondents' fathers and $6 \%$ of their mothers were university graduates compared with $28 \%$ of their sons and $30 \%$ of their daughters. $51 \%$ of fathers had not progressed beyond primary school but this applied to only $22 \%$ and $21 \%$ of their sons and daughters.

In this context we must not neglect the ways in which class advantages can be passed directly from parents to children. These advantages include consumer goods, especially houses, land, cash, investments and family farms and other businesses. Direct inter-generational transmission of class positions will have especial significance in SEM countries where roughly a third of all male 
respondents and two-fifths of their fathers who were in any employment were working for themselves or their families.

We cannot place their parents in the same employment classes that we identified among our respondents because the survey did not collect equally detailed information about parents' jobs (if any). The survey simply recorded occupational titles which were grouped into the quasi-classes in Table 7. This classification is used widely in the region. The correspondences are not exact, but the fathers' employer, tradesmen, artisan and other self-employed, and farmer groups can be compared with our respondents' business and sub-business classes. The professionals and senior managers, middle managers and other non-manuals can be compared with the salariat and sub-salariat that we identified among our respondents. The parents' skilled and unskilled (working class) jobs had been transformed into our respondents' informal and precariat classes. Forthwith we will focus on the education and employment of fathers and their sons. The education and employment classes of our female respondents are presented, but are referred to only when they are relevant to our arguments about class reproduction and re-formation.

The respondents' immediate life chances when they were children, their education, were associated with their fathers' occupations. The groups that prove distinctive by virtue of the children progressing through higher education had fathers who were professionals and senior managers $(59 \%$ of their sons had become higher education graduates), middle managers $(45 \%)$, and the selfemployed (39\%). When the fathers had been farmers, skilled or unskilled workers, or other non-manuals, only between $12 \%$ and $19 \%$ of the sons had gained higher education qualifications.

Father's education proved an even better predictor of their children's educational attainments, and the fathers' education was a good guide to their entire family households' class locations. Fathers from each educational level had a typical type of employment. For the university educated it was as professionals and senior managers, middle management for those with a full secondary education, and skilled and unskilled jobs for those whose education had finished at primary school. Those with no formal schooling were typically farmers. Other non-manuals, employers and the self-employed were from all educational levels. Fathers who were university graduates typically had graduate wives, most of whom had employment careers, usually in professional or management jobs. Just $27 \%$ of graduate mothers had been housewives or inactive in the workforce compared with between $76 \%$ and $94 \%$ of those with just secondary, primary school and no schooling. Graduate parent households were distinctive in so often having two salaries. Sixty-four percent of sons with graduate fathers and $68 \%$ of their daughters had become university graduates compared with between $9 \%$ and $33 \%$ of respondents with fathers in the other educational groups. The immediate life chances of children born into and reared in these graduate households were distinctly superior in terms of educational attainments (see Table 8). 
Table 7a. Respondents' Education by Fathers' Occupations, Male 25-29 Year Olds (in \%)

\begin{tabular}{|l|c|c|c|c|c|c|c|c|c|}
\hline & Employer & $\begin{array}{c}\text { Tradesmen } \\
\text { Artisans } \\
\text { Se1f- } \\
\text { Employed }\end{array}$ & Farmer & $\begin{array}{c}\text { Professionals } \\
\text { And Senior } \\
\text { Managers }\end{array}$ & $\begin{array}{c}\text { Middle } \\
\text { Managers }\end{array}$ & $\begin{array}{c}\text { Other Non- } \\
\text { Manuals }\end{array}$ & Skilled & Unskilled & Inactive \\
\hline Primary & $\mathbf{2 3}$ & $\mathbf{1 7}$ & $\mathbf{3 8}$ & $\mathbf{9}$ & $\mathbf{7}$ & 21 & 34 & 25 & 33 \\
\hline Secondary & $\mathbf{3 1}$ & $\mathbf{3 4}$ & $\mathbf{3 7}$ & $\mathbf{3 0}$ & $\mathbf{4 1}$ & $\mathbf{4 6}$ & $\mathbf{4 3}$ & $\mathbf{5 3}$ & $\mathbf{4 3}$ \\
\hline Vocational & $\mathbf{1 9}$ & $\mathbf{1 0}$ & $\mathbf{1 3}$ & $\mathbf{2}$ & $\mathbf{7}$ & $\mathbf{1 4}$ & $\mathbf{6}$ & $\mathbf{3}$ & $\mathbf{9}$ \\
\hline Higher & $\mathbf{2 7}$ & $\mathbf{3 9}$ & $\mathbf{1 2}$ & $\mathbf{5 9}$ & $\mathbf{4 5}$ & $\mathbf{1 9}$ & $\mathbf{1 7}$ & $\mathbf{1 9}$ & $\mathbf{1 5}$ \\
\hline N & $\mathbf{2 6}$ & $\mathbf{1 7 8}$ & $\mathbf{1 2 8}$ & $\mathbf{4 6}$ & $\mathbf{1 2 3}$ & $\mathbf{7 0}$ & $\mathbf{6 5}$ & $\mathbf{1 1 4}$ & $\mathbf{8 1}$ \\
\hline
\end{tabular}

Table 7b. Respondents' Education by Fathers' Occupations, Female 25-29 Year Olds (In \%)

\begin{tabular}{|l|c|c|c|c|c|c|c|c|c|}
\hline & Employer & $\begin{array}{c}\text { Tradesmen } \\
\text { Artisans, } \\
\text { Se1f- } \\
\text { Employed }\end{array}$ & Farmer & $\begin{array}{c}\text { Professionals } \\
\text { And } \\
\text { Senior } \\
\text { Managers }\end{array}$ & $\begin{array}{c}\text { Middle } \\
\text { Managers }\end{array}$ & $\begin{array}{c}\text { Other } \\
\text { Non- } \\
\text { Manuals }\end{array}$ & Skilled & Unskilled & Inactive \\
\hline Primary & 3 & 15 & 36 & 5 & 4 & 12 & 22 & 30 & \\
\hline Secondary & 48 & 43 & 48 & 30 & 49 & 57 & 35 & 39 & \\
\hline Vocational & 7 & 5 & 3 & 5 & 3 & 7 & 6 & 2 & 50 \\
\hline Higher & 41 & 38 & 13 & 61 & 45 & 24 & 38 & 29 & 1 \\
\hline N & 29 & 186 & 102 & 67 & 132 & 74 & 72 & 142 & \\
\hline
\end{tabular}


Table 8. Fathers' Education and 25-20 Year Old Sons' and Daughters' Highest Educational Attainments (In \%)

\begin{tabular}{|c|c|c|c|c|}
\hline & & & ther's Education & \\
\hline & None & Primary School & Secondary School & Higher \\
\hline $\begin{array}{l}\text { Male 25-29 Year } \\
\text { Olds' Attainments }\end{array}$ & & & & \\
\hline Still in Education & 7 & 7 & 11 & 18 \\
\hline Primary or Less & 35 & 21 & 6 & 1 \\
\hline Secondary & 30 & 41 & 35 & 9 \\
\hline Vocational & 18 & 15 & 15 & 9 \\
\hline Higher & 11 & 17 & 33 & 64 \\
\hline $\mathbf{N}$ & 468 & 296 & 430 & 130 \\
\hline & & b. & ther's Education & \\
\hline & None & Primary School & Secondary School & Higher \\
\hline $\begin{array}{l}\text { Female 25-29 Year } \\
\text { Olds' Attainments }\end{array}$ & & & & \\
\hline Still in Education & 4 & 7 & 7 & 15 \\
\hline Primary or Less & 39 & 19 & 6 & 2 \\
\hline Secondary & 28 & 40 & 43 & 10 \\
\hline Vocational & 19 & 8 & 11 & 6 \\
\hline Higher & 9 & 27 & 34 & 68 \\
\hline $\mathbf{N}$ & 405 & 336 & 464 & 102 \\
\hline
\end{tabular}

The education of children with a graduate father had been distinctive in other ways (see Table 9). They were the most likely to have been educated in private schools, where the language of instruction was English or French rather than Arabic, to have received additional coaching, and to have gained work experience (in internships for example). These features of their schooling may have been partly responsible for the children's superior educational attainments, but this is not the issue here. The point is that in these respects their education was distinctive.

Table 9. Fathers' and Respondents' Education (in \%)

\begin{tabular}{|l|c|c|c|c|c|}
\hline $\begin{array}{l}\text { Fathers' Educational } \\
\text { Levels }\end{array}$ & None & Primary & $\begin{array}{c}\text { Lower } \\
\text { secondary }\end{array}$ & $\begin{array}{c}\text { Full } \\
\text { secondary }\end{array}$ & Higher \\
\hline $\begin{array}{l}\text { Respondents' } \\
\text { Education, 25-29 } \\
\text { Year Olds }\end{array}$ & \multicolumn{5}{|l}{} \\
\hline In Public School & 98 & 93 & 83 & 80 & 74 \\
\hline In Arabic & 91 & 72 & 66 & 64 & 60 \\
\hline $\begin{array}{l}\text { Received Some } \\
\text { Private Tutoring }\end{array}$ & 23 & 27 & 24 & 37 & 49 \\
\hline $\begin{array}{l}\text { Gained Work } \\
\text { Experience During } \\
\text { Education }\end{array}$ & 16 & 21 & 26 & 32 & 51 \\
\hline N & 900 & 678 & 446 & 376 & 192 \\
\hline
\end{tabular}

Now let us re-examine the data in some of the preceding tables from a different angle. The picture changes in the tables that follow. Only $25 \%$ of the sons and $20 \%$ of the daughters with university qualifications had graduate fathers 
(Table 10). There were more graduate sons and daughters whose fathers had only secondary schooling. There were also more where the father had just primary schooling or none at all. This is what happens when education systems expand upwards. First secondary schools then higher education become sites where young people from diverse backgrounds inter-mingle.

Table 10. Fathers' Education by 25-20 Year Old Sons' and Daughters' Highest Educational Attainments (in \%)

\begin{tabular}{|c|c|c|c|c|}
\hline \multicolumn{5}{|c|}{ Male 25-29 Year Olds' Attainments } \\
\hline & Primary Or Less & Secondary & Vocational & Higher \\
\hline \multicolumn{5}{|c|}{ Father's Education } \\
\hline None & 65 & 33 & 41 & 15 \\
\hline Primary & 25 & 29 & 21 & 15 \\
\hline Secondary & 10 & 35 & 32 & 44 \\
\hline Higher & $<1$ & 3 & 6 & 25 \\
\hline $\mathbf{N}$ & 122 & 423 & 205 & 326 \\
\hline \multicolumn{5}{|c|}{ Female 25-29 Year Olds' Attainments } \\
\hline & Primary Or Less & Secondary & Vocational & Higher \\
\hline \multicolumn{5}{|c|}{ Father's Education } \\
\hline None & 62 & 24 & 47 & 10 \\
\hline Primary & 25 & 29 & 17 & 25 \\
\hline Secondary & 11 & 43 & 32 & 45 \\
\hline Higher & 1 & 2 & 4 & 20 \\
\hline $\mathbf{N}$ & 87 & 457 & 161 & 353 \\
\hline
\end{tabular}

What is more, a university degree no longer guaranteed a salariat job. This was not the main labour market destination of our male or female graduates (Table 11). Just $23 \%$ of both sexes had salariat or sub-salariat jobs. $64 \%$ of the male and $73 \%$ of the female university graduates were in the informal or precariat classes or detached from the labour market. Most respondents with fathers in all types of employment, and with all levels of education, had these same destinations.

Table 11. a. Respondents' Employment Classes by Respondents' Education, Male 25-29 Year Olds (in \%)

\begin{tabular}{|l|c|c|c|c|}
\hline \multicolumn{5}{|c|}{ Highest Educational Attainment } \\
\hline & Primary or Less & Secondary & Vocational & Higher \\
\hline 1a. Business Class & 4 & 13 & 6 & 10 \\
\hline 1b. Sub-Business Class & 14 & 9 & 9 & 4 \\
\hline 2a. Salariat & 3 & 10 & 6 & 19 \\
\hline 2b.Sub-Salariat & 2 & 2 & 5 & 4 \\
\hline 3. Informals & 24 & 25 & 38 & 27 \\
\hline 4. Precariat & 35 & 26 & 31 & 19 \\
\hline 5. Detached & 18 & 16 & 8 & 18 \\
\hline N & 238 & 385 & 196 & 313 \\
\hline
\end{tabular}


b. Respondents' Employment Classes by Respondents' Education, Female 2529 Year Olds (in \%)

\begin{tabular}{|l|c|c|c|c|}
\hline \multicolumn{5}{|c|}{ Highest Educational Attainment } \\
\hline & Primary or Less & Secondary & Vocational & Higher \\
\hline 1a. Business Class & - & 2 & 3 & 3 \\
\hline 1b. Sub-Business Class & $<1$ & 1 & 3 & 1 \\
\hline 2a. Salariat & - & 3 & 2 & 20 \\
\hline 2b.Sub-Salariat & - & 1 & 4 & 3 \\
\hline 3. Informals & 6 & 8 & 5 & 16 \\
\hline 4. Precariat & 18 & 12 & 13 & 19 \\
\hline 5. Detached & 76 & 73 & 70 & 38 \\
\hline N & 239 & 441 & 159 & 347 \\
\hline
\end{tabular}

How had this happened? The explanation is demographic. During the second half of the $20^{\text {th }}$ century the populations of SEM countries had doubled then doubled again (Table 12). Before the end of the $20^{\text {th }}$ century it was predicted that the latest 'demographic surge' would become a labour market disaster unless something was done (Population Council 1998).

Table 12. Populations (in Millions)

\begin{tabular}{|l|c|c|c|c|}
\hline & $\mathbf{1 9 5 0}$ & $\mathbf{1 9 8 0}$ & $\mathbf{2 0 1 0}$ & $\mathbf{2 0 1 7}$ \\
\hline Algeria & 9 & 19 & 36 & 41 \\
\hline Egypt & 22 & 43 & 82 & 95 \\
\hline Lebanon & 1 & 3 & 4 & 6 \\
\hline Morocco & 9 & 20 & 32 & 35 \\
\hline Tunisia & 3 & 6 & 11 & 11 \\
\hline
\end{tabular}

The something that actually happened in described in Table $13.42 \%$ of the employed fathers of our respondents had been employers, self-employed or farmers but only $21 \%$ of male respondents were in the business or sub-business classes. Just $15 \%$ of the male respondents had salariat or sub-salariat jobs compared with $34 \%$ of the fathers. The crude numbers in such jobs had not shrunk but they accounted for much smaller proportions of the respondents' birth cohort. The $25 \%$ of fathers who had been skilled or unskilled workers had been replaced by the $64 \%$ of sons who were in the informal or precariat classes. Unregulated labour markets alongside the absence of state welfare support for the young unemployed had averted 'disastrous' levels of unemployment by permitting the creation of swaths of informal, low paid and other precarious jobs. Young women who had emulated their mothers in remaining outside the labour market had eased the excess of labour seeking livelihoods.

When the countries of the SEM region had been colonies of Turkey and European powers, the imperial rulers had established secondary schools and universities to educate locals for positions in public administration and services and to fill non-manual occupations in private businesses (see Allison 2015, Hinnebusch 2015, Sumpf 2014). The United Nations Economic and Social Commission for Western Asia (2014) estimates that an outcome was that around a half of the local populations became middle class in terms of their occupations or 
having at least some secondary schooling. This estimate accords with our findings on the occupations and education of respondents' fathers. Their children, our respondents, had been unable to replicate these achievements. Whatever their parents' education and occupations, and whatever the respondents' own educational attainments, their most likely labour force destinations had been in informal or precarious employment, or no employment. It has been argued that pre-2011 and the protests known as the Arab Spring, the ruling regimes in SEM countries had lost the support of the middle classes through cutbacks in public spending on which middle class lifestyles depended, particularly public sector jobs (see Kandil 2012, Sumpf 2014). However, we suspect that a greater source of middle class discontent will have been the inability of middle class children to replicate their parents' achievements even when the children had done everything that formerly had been both necessary and sufficient, namely completing university or even just secondary school.

Table 13. Employment Classes of Fathers and 25-29 Year Olds Sons (in \%)

\begin{tabular}{|l|c|c|c|}
\hline \multicolumn{1}{|c|}{ Fathers } & 42 & 21 & $\begin{array}{l}\text { Business Class and Sub- } \\
\text { Business Class }\end{array}$ \\
\hline $\begin{array}{l}\text { Employers, Farmers, Artisans, Self- } \\
\text { Employed }\end{array}$ & 34 & 15 & Salariat and Sub-Salariat \\
\hline $\begin{array}{l}\text { Professionals and Senior Managers, } \\
\text { Middle Managers and Other Non- } \\
\text { Manuals }\end{array}$ & 25 & 64 & Informals and Precariat \\
\hline Skilled and Unskilled Workers &
\end{tabular}

Whatever their fathers' levels of education and types of employment, majorities of 25-29 year old respondents were in the informal or precariat classes or detached from the labour market. Class reproduction, it appears, had broken down. It had begun in education then stalled and collapsed when the young adults entered the labour market.

\section{Routes and Destinations}

This is not the end of our own narrative, or our respondents' life stories. We are not going to illustrate that statistics can be made to prove anything; just that there are different ways of viewing our data that reveal different features of the same reality. The young people had embarked into youth from families in different class locations which had conferred different life chances. Those with the most distinctive educational biographies had fathers who were higher education graduates and held professional or senior management jobs. They were the males who were most likely to progress through higher education. However, once in higher education, if not in the secondary schools that they had attended, they intermingled with students from all kinds of family backgrounds. After completing their education, sons of fathers with professional or senior management jobs, like university graduates, were most likely to find themselves restricted to informal or precariat jobs. The labour markets that they entered made it impossible for the majority to reproduce their families' class positions, and this would have applied even in conditions of zero relative social mobility. This is because the number of 
positions in the more privileged classes had not grown as rapidly as the countries' populations, and some classes had undergone radical changes of character.

Table 14. a. Respondents' Education by Respondents' Employment Classes, Male 25-29 Year Olds (in \%)

\begin{tabular}{|l|c|c|c|c|c|c|c|}
\hline & $\begin{array}{c}\text { 1a. } \\
\text { Business } \\
\text { Class }\end{array}$ & $\begin{array}{c}\text { 1b. Sub- } \\
\text { Business } \\
\text { Class }\end{array}$ & $\begin{array}{c}\mathbf{2 a} \text {. } \\
\text { Salariat }\end{array}$ & $\begin{array}{c}\mathbf{2 b .} \\
\text { Sub- } \\
\text { Salariat }\end{array}$ & $\begin{array}{c}\text { 3. } \\
\text { Informals }\end{array}$ & $\begin{array}{c}\mathbf{4 .} \\
\text { Precariat }\end{array}$ & $\begin{array}{c}\mathbf{5 .} \\
\text { Detached }\end{array}$ \\
\hline $\begin{array}{l}\text { Primary } \\
\text { or Less }\end{array}$ & 10 & 34 & 5 & 15 & 19 & 28 & 25 \\
\hline Secondary & 49 & 36 & 33 & 21 & 31 & 33 & 36 \\
\hline Vocational & 12 & 18 & 11 & 27 & 24 & 20 & 7 \\
\hline Higher & 30 & 12 & 52 & 38 & 27 & 20 & 33 \\
\hline N & 101 & 97 & 114 & 34 & 311 & 301 & 174 \\
\hline
\end{tabular}

b. Respondents' Education by Respondents' Employment Classes, Female 25-29 Year Olds (in \%)

\begin{tabular}{|l|c|c|c|c|c|c|c|}
\hline & $\begin{array}{c}\text { 1a. } \\
\text { Business } \\
\text { Class }\end{array}$ & $\begin{array}{c}\text { 1b. Sub- } \\
\text { Business } \\
\text { Class }\end{array}$ & $\begin{array}{c}\mathbf{2 a} \text { Salariat } \\
\text { Salat }\end{array}$ & $\begin{array}{c}\mathbf{2 b} . \\
\text { Sub- } \\
\text { Salariat }\end{array}$ & $\begin{array}{c}\text { 3. } \\
\text { Informals }\end{array}$ & $\begin{array}{c}\mathbf{4 .} \\
\text { Precariat }\end{array}$ & $\begin{array}{c}\mathbf{5 .} \\
\text { Detached }\end{array}$ \\
\hline $\begin{array}{l}\text { Primary } \\
\text { Or Less }\end{array}$ & - & 8 & - & - & 13 & 23 & 24 \\
\hline Secondary & 41 & 39 & 13 & 24 & 30 & 29 & 43 \\
\hline Vocational & 18 & 31 & 4 & 33 & 7 & 11 & 15 \\
\hline Higher & 41 & 23 & 83 & 43 & 50 & 36 & 18 \\
\hline N & 22 & 13 & 84 & 21 & 114 & 184 & 748 \\
\hline
\end{tabular}

Despite all this, male respondents who obtained salariat jobs would have found that just over a half $(52 \%)$ of their salariat peers were higher education graduates, far more than in any other class (Table 14). This was despite only $18 \%$ of male graduates obtaining salariat jobs. Those who had joined the salariat had become part of the class whose young entrants were better qualified, and also better paid, than most graduates (who had entered other kinds of employment). $46 \%$ of salariat sons had fathers with salariat-equivalent occupations compared with just $29 \%$ of all male respondents.

The business class's collective biographies were rather different. They were distinguished not by their education but by $40 \%$ having fathers who were employers or self-employed, more than in any other class. This was despite only $25 \%$ of male respondents having fathers who were employers or self-employed and only $18 \%$ of these males having joined the business class. A further $27 \%$ of business class sons had fathers in salariat occupations. $28 \%$ of males in the salariat had fathers who were employers or self-employed. So $67 \%$ of the business class had fathers with these combined backgrounds, as did $64 \%$ of those in salariat jobs. There had been a significant volume of inter-generational inter-change between these two top classes Table 15).

The two remaining classes - the informals and the precariat (ignoring for present purposes the subs and the mainly female detached group) were barely distinguishable from one another in terms of their members' biographies. In each 
case they were drawn from all educational levels - none was predominant - and their fathers were scattered fairly evenly throughout the occupational structure. They were simply 'the people'. Whether they had left education after primary school or graduated from university seemed to have made no difference on entering the labour market. 'No difference' must have been the experience of the majority of 25-29 year old males because most had entered one of these classes the informals, the precariat and the detached.

In contrast, those who were succeeding in business would have known that this alone made them distinctive, and they were likely to believe that their success was not due to pure luck but to their own capabilities and efforts. These capabilities would have been gained partly during childhoods in business families. The salariat would have known that they were different not only by virtue of their types of jobs, but also by being among the minority of their age group with university qualifications, and having grown up in families with fathers (and often mothers also) with salariat-type jobs. These backgrounds may well have enabled them to acquire useful cultural and social assets which had made them attractive salariat recruits and competent employees.

We have seen that there had been considerable inter-generational 'exchanges' between the salariat and business classes, so it is possible to treat them as very different but connected sections of their countries' middle classes. The business and salariat classes can be expected to have their own children educated in ways, in the conditions that then prevail, which give the next family generation the best possible starts in life. If so, class reproduction will continue despite the merging and inter-mingling that occurs during school and higher education. Our evidence shows that reproduction can continue while countries' economies, labour markets and social classes undergo major transformation. Youth research is uniquely able to identify these outcomes and the intervening processes.

Table 15. a. Father's Occupations by Respondents' Employment Classes, Male 2529 Year Olds (in \%)

\begin{tabular}{|l|c|c|c|c|c|c|c|}
\hline & $\begin{array}{c}\text { 1a. } \\
\text { Business } \\
\text { Class }\end{array}$ & $\begin{array}{c}\text { 1b. Sub- } \\
\text { Business } \\
\text { Class }\end{array}$ & $\begin{array}{c}\mathbf{2 a .} \\
\text { Salariat }\end{array}$ & $\begin{array}{c}\mathbf{2 b .} \\
\text { Sub- } \\
\text { Salariat }\end{array}$ & $\begin{array}{c}\mathbf{3 .} \\
\text { Informals }\end{array}$ & $\begin{array}{c}\mathbf{4 .} \\
\text { Precariat }\end{array}$ & $\begin{array}{c}\mathbf{5 .} \\
\text { Detached }\end{array}$ \\
\hline Employer & 2 & 3 & 1 & - & 4 & 4 & 4 \\
\hline $\begin{array}{l}\text { Self- } \\
\text { Employed }\end{array}$ & 38 & 16 & 27 & - & 18 & 18 & 20 \\
\hline Farmer & 14 & 30 & 12 & 8 & 14 & 16 & 13 \\
\hline $\begin{array}{l}\text { Professional } \\
\text { Or Senior } \\
\text { Manager }\end{array}$ & 6 & 3 & 6 & 8 & 7 & 4 & 6 \\
\hline $\begin{array}{l}\text { Middle } \\
\text { Management }\end{array}$ & 13 & 1 & 32 & 15 & 19 & 11 & 9 \\
\hline $\begin{array}{l}\text { Other Non- } \\
\text { Manual }\end{array}$ & 8 & 10 & 8 & 8 & 10 & 6 & 10 \\
\hline Skilled & 5 & 8 & 3 & 15 & 9 & 11 & 7 \\
\hline Unskilled & 5 & 18 & 9 & 8 & 12 & 20 & 15 \\
\hline Inactive & 7 & 12 & 2 & 39 & 8 & 10 & 16 \\
\hline N & 97 & 74 & 109 & 13 & 201 & 188 & 149 \\
\hline
\end{tabular}


b. Father's Occupations by Respondents' Employment Classes, Female 25-29 Year Olds (in Percentages)

\begin{tabular}{|l|c|c|c|c|c|c|c|}
\hline & $\begin{array}{c}\text { 1a. } \\
\text { Business } \\
\text { Class }\end{array}$ & $\begin{array}{c}\text { 1b. Sub- } \\
\text { Business } \\
\text { Class }\end{array}$ & $\begin{array}{c}\mathbf{2 a .} \\
\text { Salariat }\end{array}$ & $\begin{array}{c}\mathbf{2 b} \text { b. } \\
\text { Sub- } \\
\text { Salariat }\end{array}$ & $\begin{array}{c}\mathbf{3 .} \\
\text { Informals }\end{array}$ & $\begin{array}{c}4 . \\
\text { Precariat }\end{array}$ & $\begin{array}{c}\mathbf{5 .} \\
\text { Detached }\end{array}$ \\
\hline Employer & - & - & 2 & 8 & 7 & 1 & 3 \\
\hline $\begin{array}{l}\text { Self- } \\
\text { Employed }\end{array}$ & 36 & 8 & 33 & 2 & 16 & 18 & 21 \\
\hline Farmer & 5 & 23 & 6 & 8 & 12 & 14 & 12 \\
\hline $\begin{array}{l}\text { Professional } \\
\text { Or Senior } \\
\text { Manager }\end{array}$ & 23 & 8 & 13 & - & 11 & 10 & 5 \\
\hline $\begin{array}{l}\text { Middle } \\
\text { Management }\end{array}$ & 14 & - & 27 & 17 & 19 & 10 & 14 \\
\hline $\begin{array}{l}\text { Other Non- } \\
\text { Manual }\end{array}$ & 9 & 23 & 11 & 33 & 8 & 5 & 8 \\
\hline Skilled & 5 & 15 & - & - & 14 & 12 & 8 \\
\hline Unskilled & 5 & 23 & 4 & 8 & 12 & 22 & 18 \\
\hline Inactive & 5 & - & 5 & - & 3 & 8 & 10 \\
\hline N & 22 & 13 & 83 & 12 & 102 & 147 & 495 \\
\hline
\end{tabular}

\section{Conclusions}

Among the classes that we have identified, the business class and the salariat must be regarded as those most likely to already exist as, or to develop into, social classes with distinctive socio-cultural features. There is no space here to search for such distinctiveness in our evidence, but we have demonstrated that these classes alone have the necessary demographic coherence. They are the classes where those who had joined were the most likely to remain, where the entrants had the most distinctive, characteristic biographies, and children reared by parents who belonged to the equivalents of our respondents' business and salariat classes were the young people with the most distinctive (and advantaged) life chances. The other classes that we have identified - the informals and the precariat - lacked demographic coherence, while females accounted for most of the detached group and would share their husbands' class positions after marriage, and remained part of their parents' classes while they remained living in their childhood family homes.

Youth in SEM countries are divided by gender. There are differences in the opportunities of those who live in rural and urban areas. In addition, and most important, they are divided into very unequal classes. The entire life stage group is anything but a coherent class with one distinctive position in the labour market. There has been a major inter-generational deterioration in their labour market opportunities, but not for them all, certainly not to the same extent. The business and salariat classes are recognisable in the occupations of respondents' parents, and these are the classes where the largest proportions of young people remained in their parents' classes. For these young people, class reproduction and the inheritance of positions has survived the radical re-formation of employment classes in the SEM countries. 
Our evidence and therefore our conclusions are mostly specific to these countries, but certain findings are likely to travel well. Education may sometimes be a mobility channel, but it is also able to screen and render opaque the extent to which the 'winners' among young people were born into and reared in advantaged families. Youth research is uniquely able to show how this is possible.

\section{References}

Allison J (2015) Class forces, transition and the Arab uprisings: a comparison of Tunisia, Egypt and Syria. Democratization 22: 294-314.

Bourdieu P $(1979,1984)$ Distinction: A Social Critique of the Judgment of Taste. London: Routledge.

Bourdieu P, Passerson JC (1970, 1977) Reproduction in Education, Society and Culture. London: Sage.

Charles N (1990) Women and class: a problematic relationship. Sociological Review 38: 43-89.

Erikson R, Goldthorpe JH (1988) 'Women at class crossroads: a critical note'. Sociology 22: 545-553.

Evans G, Mills C (1999) Are there classes in post-communist societies? Sociology 33: 2346.

Farsoun S (2006) Class structure and social change in the Arab world. In Hopkins N, Ibrahim S (eds) Arab Society: Class, Gender, Power, and Development, 1-28. Cairo: American University in Cairo Press.

Ganzeboom HBG, De Graaf PM, Treiman DJ (1992) A standard international socioeconomic index of occupational status. Social Science Research 21: 1-50.

Goldthorpe JH (1983) Women and class analysis. Sociology 17: 465-488.

Hinnebusch R (2015) Change and continuity after the Arab uprising: the consequences of state formation in Arab North African states. British Journal of Middle Eastern Studies 42: 12-30.

Kandil H (2012) Why did the Egyptian middle class march to Tahrir Square? Mediterranean Politics 17: 197-215.

Leiulfsrud H, Woodward A (1987) Women at class crossroads: repudiating conventional theories of family class. Sociology 21: 393-412.

Montieth W, Giesbert L (2016) "When the stomach is full we look for respect": perceptions of "good work" in the urban informal sectors of three developing countries. Work, Employment and Society. doi: 10.1177/0950017016650606.

Population Council (1998) Adolescence and Social Change in Egypt. Cairo: Population Council.

Prandy K (1990) The revised Cambridge scale of occupations. Sociology 24: 629-655.

Prandy K (1998) Deconstructing classes: critical comments on the revised social classification. Work, Employment and Society 12: 743-753.

Roberts K, Pollock G (2009) New class divisions in the new market economies: evidence from the careers of young adults in post-Soviet Armenia, Azerbaijan and Georgia. Journal of Youth Studies 12: 579-596.

Roberts K, Pollock F (2011) Class in the South Caucasus. European Societies 13: 757782.

Rose D (1998) Once more unto the breach: in defence of class analysis once again. Work, Employment and Society 12: 755-767.

Rose D, Harrison E (2007) The European Socio-Economic Classification: a new social 
class scheme for comparative European research. European Societies 9: 459-490.

Savage M, Devine F, Cunningham N, Taylor M, Li Y, Hjellbrekke J, Roux BL, Friedman S,Miles A (2013) A new model of social class? Findings from the BBC's Great British Class Survey experiment. Sociology 47: 219-250.

Shenker J (2016) The Egyptians: A Radical Story. London: Allen Lane.

Stanworth M (1984) Women at class crossroads: a reply to Goldthorpe. Sociology 18: $159-170$.

Storm L (2014) Party Politics and the Prospects for Democracy in North Africa. Boulder: Lynne Riener Publishers.

Sumpf D (2014) The Middle Class in the Arab Region and Their Political Participation: A Research and Policy Agenda.UN-ESCWA Economic Development and Globalization Division Working Paper Series, Beirut.

United Nations Economic and Social Commission for Western Asia (2014) Arab Middle Class Measurement and Role in Driving Change.ESCWA, Beirut.

Woodman D, Wyn J (2015) Youth and Generation: Rethinking Change and Inequality in the Lives of Young People. London: Sage.

Wright EO (1979) Class, Crisis and the State. London:Verso.

Wright EO (1985) Classes. London: Verso.

Wright EO (1994) Interrogating Inequality. New York: Verso.

Wright EO (1996) Class Counts. Cambridge: Cambridge University Press.

Wright EO (2000) Working class power, capitalist class interests, and class compromise. American Journal of Sociology 105: 957-1002. 